\title{
Description of Pelomonas aquatica sp. nov. and Pelomonas puraquae sp. nov., isolated from industrial and haemodialysis water
}

\section{Correspondence Jorge Lalucat jlalucat@uib.es}

\author{
Margarita Gomila, ${ }^{1}$ Botho Bowien, ${ }^{2}$ Enevold Falsen, ${ }^{3}$ Edward R. B. Moore ${ }^{3}$ \\ and Jorge Lalucat ${ }^{1}$
}

\author{
${ }^{1}$ Área Microbiologia, Departament de Biologia, Universitat de les Illes Balears, and Institut \\ Mediterrani d'Estudis Avançats (CSIC-UIB), 07122 Palma de Mallorca, Illes Balears, Spain \\ ${ }^{2}$ Abt. Molekularphysiologie, Institut für Mikrobiologie und Genetik, Georg-August-Universität \\ Göttingen, 37077 Göttingen, Germany \\ ${ }^{3}$ CCUG, Culture Collection University of Göteborg, Department of Clinical Bacteriology, \\ 41346 Göteborg, Sweden
}

Three Gram-negative, rod-shaped, non-spore-forming bacteria (strains CCUG $52769^{\top}$, CCUG 52770 and CCUG 52771) isolated from haemodialysis water were characterized taxonomically, together with five strains isolated from industrial waters (CCUG 52428, CCUG 52507, CCUG $52575^{\top}$, CCUG 52590 and CCUG 52631). Phylogenetic analysis based on $16 \mathrm{~S}$ rRNA gene sequences indicated that these isolates belonged to the class Betaproteobacteria and were related to the genus Pelomonas, with 16S rRNA gene sequence similarities higher than $99 \%$ with the only species of the genus, Pelomonas saccharophila and to Pseudomonas sp. DSM 2583. The type strains of Mitsuaria chitosanitabida and Roseateles depolymerans were their closest neighbours (97.9 and 97.3\% 16S rRNA gene sequence similarity, respectively).

Phylogenetic analysis was also performed for the internally transcribed spacer region and for three genes [hoxG (hydrogenase), cbbL/cbbM (Rubisco) and nifH (nitrogenase)] relevant for the metabolism of the genus Pelomonas. DNA-DNA hybridization, major fatty acid composition and phenotypical analyses were carried out, which included the type strain of Pelomonas saccharophila obtained from different culture collections (ATCC $15946^{\top}$, CCUG $32988^{\top}$, DSM $654^{\top}$, IAM $14368^{\top}$ and LMG $2256^{\top}$ ), as well as M. chitosanitabida IAM $14711^{\top}$ and $R$. depolymerans CCUG $52219^{\top}$. Results of DNA-DNA hybridization, physiological and biochemical tests supported the conclusion that strains CCUG 52769, CCUG 52770 and CCUG 52771 represent a homogeneous phylogenetic and genomic group, including strain DSM 2583, clearly differentiated from the industrial water isolates and from the Pelomonas saccharophila type strain. On the basis of phenotypic and genotypic characteristics, these strains belong to two novel species within the genus Pelomonas, for which the names Pelomonas puraquae sp. nov. and Pelomonas aquatica sp. nov. are proposed. The type strains of Pelomonas puraquae sp. nov. and Pelomonas aquatica sp. nov. are CCUG $52769^{\top}\left(=\right.$ CECT $\left.7234^{\top}\right)$ and CCUG $52575^{\top}(=$ CECT $7233^{\top}$ ), respectively.
Pseudomonas saccharophila has been isolated from mud as a facultative chemolithoautotrophic hydrogen-oxidizing bacterium (Doudoroff, 1940) and this single strain was

\section{Abbreviation: ITS, internally transcribed spacer.}

The GenBank/EMBL/DDBJ accession numbers for the novel strains are: CCUG 52575 ${ }^{\top}$ (AM51435 and AM501454, for 16S rRNA gene and ITS1, respectively), and for strain CCUG 52769 ${ }^{\top}$ [AM501439, AM501458, AM501467 and AM501476, for 16S rRNA gene, ITS1, nifH and red-like form I Rubisco genes ( $c b b L$ ), respectively].

Supplementary data are available with the online version of this paper. subsequently intensively investigated for its carbohydrate metabolism (Doudoroff et al., 1956). Much later Palleroni (1980) described a hydrogen-oxidizing bacterium, Pseudomonas sp. DSM 2583, related to Pseudomonas saccharophila. This new organism shared the basic physiological properties with Pseudomonas saccharophila, but could be easily differentiated by substrate assimilation tests and by DNA-DNA hybridizations. However, it was not proposed as a novel species until other strains of the group were isolated from nature. The nitrogen-fixing ability of the type strain of Pseudomonas saccharophila was later 
demonstrated by Barraquio et al. (1986). Other strains ascribed to Pelomonas saccharophila have been studied as degraders of aromatic compounds (Stringfellow \& Aitken, 1995) and contaminants of pure and ultrapure waters (Kulakov et al., 2002; Gomila et al., 2005). Considering only the type strain, Xie \& Yokota (2005) reclassified the type strain of Pseudomonas saccharophila into a new genus, Pelomonas.

In a previous study, haemodialysis water was analysed to monitor its microbiological quality and to identify the bacteria present in this oligotrophic environment (Gomila et al., 2005, 2006). During this study, a group of three strains forming clear brown colonies on R2A agar was isolated from two different samples taken at the same point. The strains were identified by $16 \mathrm{~S}$ rRNA gene sequences members of the class Betaproteobacteria, closely related to Pelomonas saccharophila (formerly Pseudomonas saccharophila). The present study was undertaken to determine the taxonomic position of nine different strains. Strains CCUG 52769 ${ }^{\mathrm{T}}$, CCUG 52770 (=MG64) and CCUG 52771 (=MG63) were isolated on R2A medium (Reasoner \& Geldreich, 1985) from haemodialysis water at the Hospital Son Llàtzer (Mallorca, Spain). Five strains deposited at the CCUG as members of the genus Pelomonas were isolated from industrial water in Sweden (CCUG 52428, CCUG 52507, CCUG 52575 ${ }^{\mathrm{T}}$, CCUG 52590 and CCUG 52631). The following previously described species were also used in this study: five cultures of the type strain of Pelomonas saccharophila were obtained from the corresponding culture collections (ATCC $15946^{\mathrm{T}}$, CCUG $32988^{\mathrm{T}}$, DSM $654^{\mathrm{T}}$, IAM $14368^{\mathrm{T}}$ and LMG $2256^{\mathrm{T}}$ ); strain DSM 2583 (=CCUG 52768), described by Palleroni (1980); the type strain of Mitsuaria chitosanitabida IAM $14711^{\mathrm{T}}$ (=CCUG $52767^{\mathrm{T}}$ ); and the type strain of Roseateles depolymerans CCUG $52219^{\mathrm{T}}\left(=\mathrm{DSM} 11813^{\mathrm{T}}\right)$. All strains were cultured in R2A medium containing $\left(1^{-1}\right)$ : 0.5 g yeast extract, $0.5 \mathrm{~g}$ acid hydrolysate of casein, $0.5 \mathrm{~g}$ glucose, $0.5 \mathrm{~g}$ starch, $0.3 \mathrm{~g} \mathrm{~K}_{2} \mathrm{HPO}_{4}, 0.3 \mathrm{~g}$ sodium pyruvate, $0.25 \mathrm{~g}$ pancreatic digest of casein, $0.25 \mathrm{~g}$ peptic digest of animal tissue and $0.0492 \mathrm{~g} \mathrm{MgSO}_{4} \cdot 7 \mathrm{H}_{2} \mathrm{O}$, supplemented with $1.5 \%(\mathrm{w} / \mathrm{v})$ agar for the plates. Bacteria were incubated for $3-4$ days at $30{ }^{\circ} \mathrm{C}$ unless otherwise stated. Colonies of the haemodialysis water isolates and Pseudomonas sp. DSM 2583 grown on R2A agar for 5 days were $4-5 \mathrm{~mm}$ in diameter, pale brown being darker in the centre, circular, raised with entire margin, smooth and translucent. They could easily be removed from the agar. The industrial water isolates formed colonies of a smaller size $(1-2 \mathrm{~mm})$ and a different colour (homogeneous yellowish) being darker and opaque, and were more difficult to recultivate after 1 week of incubation, similar to colonies of the Pelomonas saccharophila type strain.

Cell size, morphology and flagella insertion were determined by transmission electron microscopy of cells from the exponential growth phase in R2A broth. A Hitachi model $\mathrm{H} 600$ electron microscope was used at $75 \mathrm{kV}$. The samples were negatively stained with phosphotungstic acid
(1\%, pH 7.0) as described by Lalucat (1988). Cells were rod-shaped ( $2 \mu \mathrm{m}$ in length), Gram-negative, and motile by means of a single polarly inserted flagellum (Fig. 1).

The following phenotypic tests were carried out: API 20NE (identification system for Gram-negative, non-enterobacterial rods) and API $50 \mathrm{CH}$, according to the manufacturer's instructions. Biolog tests were also carried out as follows: a homogeneous suspension of inoculum was made in the GN/GP inoculating fluid and $150 \mu \mathrm{l}$ of the suspension was dispensed into each well of the GN Microlog microplate, which was incubated for up to $96 \mathrm{~h}$ at the optimal growth temperature of the bacteria. The absorbance values were recorded periodically over a 4 day period, at $0,4,8 \mathrm{~h}$, after $24,48,72$ and $96 \mathrm{~h}$ incubation time using an automated Microplate reader. Absorbance was measured in dual wavelengths mode, at $590 \mathrm{~nm}$ (respiratory reduction of tetrazolium dye to form formazane that absorbs light at $590 \mathrm{~nm}$ ) and at $750 \mathrm{~nm}$ as a second reference wavelength. Conventional phenotypic tests were done according to Cowan (1974). Growth rate was determined at different temperatures in R2A medium $\left(4,10,20,30,37\right.$ and $\left.45^{\circ} \mathrm{C}\right)$ and aerobic autotrophic growth with hydrogen was tested in mineral medium as described by Aragno \& Schlegel (1992) at different $\mathrm{O}_{2}$ partial pressures. All strains grew at 20 and $30{ }^{\circ} \mathrm{C}$. The range of temperatures for heterotrophic growth is indicated in Table 1. The type strain of Pelomonas saccharophila and Pseudomonas sp. DSM 2583 grew autotrophically with hydrogen at $30{ }^{\circ} \mathrm{C}$ in mineral medium under an atmosphere of $\mathrm{H}_{2} / \mathrm{O}_{2} / \mathrm{CO}_{2}(80: 10: 10,85: 5: 10$ or $88: 2: 10$; \% by vol.). Strains CCUG $52769^{\mathrm{T}}$, CCUG 52770 and CCUG 52771 also grew autotrophically with hydrogen but slowly (10 days). None of the five industrial water isolates was able to grow under these conditions, nor were $M$. chitosanitabida IAM $14711^{\mathrm{T}}$ and $R$. depolymerans CCUG $52219^{\mathrm{T}}$. Carbon sources utilized are indicated in the formal

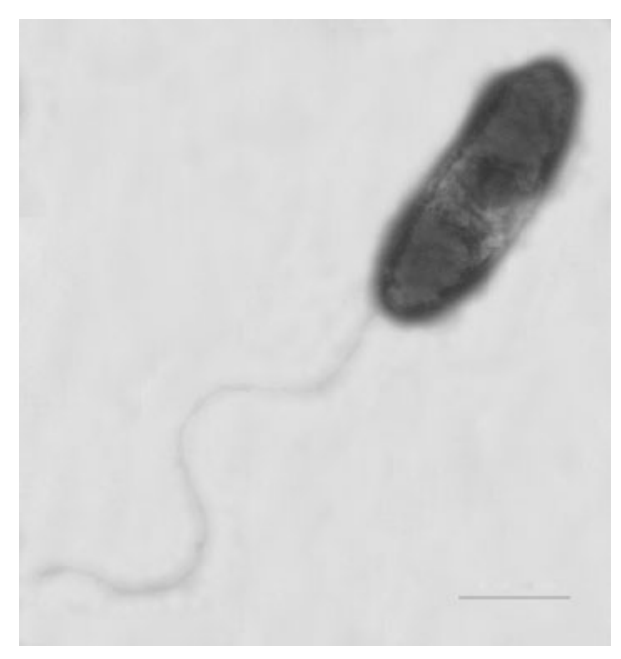

Fig. 1. Cell morphology of strain CCUG $52769^{\top}$ observed by transmission electron microscopy. Bar, $1.5 \mu \mathrm{m}$. 
Table 1. Differential phenotypic characteristics between species of the genera Mitsuaria, Roseateles and Pelomonas

Strains/species: 1, M. chitosanitabida IAM $14711^{\mathrm{T}} ; 2$, R. depolymerans CCUG 52219 ${ }^{\mathrm{T}}$; 3, Pelomonas saccharophila CCUG 32988 ${ }^{\mathrm{T}}$; 4, DSM 2583; 5 , CCUG 52769 ${ }^{\mathrm{T}}$; 6, CCUG 52770; 7, CCUG 52771; 8, CCUG 52428; 9, CCUG 52507; 10, CCUG 52575 ; 11, CCUG 52590; 12 , CCUG 52631. +, Positive; - , negative; \pm , weak; $+/-$, variable; ND, not determined.

\begin{tabular}{|c|c|c|c|c|c|c|c|c|c|c|c|c|}
\hline Characteristic & 1 & 2 & 3 & 4 & 5 & 6 & 7 & 8 & 9 & 10 & 11 & 12 \\
\hline 10 & + & + & - & + & + & + & + & - & - & - & - & - \\
\hline Phototrophic growth & - & $+^{*}$ & - & - & - & - & - & - & - & - & - & - \\
\hline Autotrophic growth with $\mathrm{H}_{2}$ & - & - & + & + & Slow & Slow & Slow & ND & $\mathrm{ND}$ & - & - & - \\
\hline Bacteriochlorophyll $a$ & - & $+^{*}$ & - & - & - & - & - & - & - & - & - & - \\
\hline nifH & - & + & + & + & + & + & + & - & - & - & - & - \\
\hline$c b b L$ & - & - & + & + & + & + & + & - & - & - & - & - \\
\hline hoxG & - & - & $\mathrm{ND}$ & ND & + & + & + & - & - & - & - & - \\
\hline Nitrate reduction & + & - & + & + & - & - & - & + & + & + & + & + \\
\hline Urease & - & + & - & - & - & - & - & - & - & - & - & - \\
\hline Gelatin hydrolysis & + & + & - & + & + & + & + & - & - & - & - & - \\
\hline D-Mannose & - & + & $+1-$ & - & - & - & - & - & - & - & - & - \\
\hline D-Mannitol & - & + & - & - & - & - & - & - & - & - & - & - \\
\hline$N$-Acetyl-D-glucosamine & - & - & + & - & - & - & - & - & - & - & - & - \\
\hline Maltose & + & + & + & + & + & + & + & - & - & - & - & - \\
\hline Gluconate & + & + & + & - & - & - & - & - & - & - & - & - \\
\hline Capric acid & + & \pm & - & - & - & - & - & - & - & - & - & - \\
\hline Adipic acid & - & \pm & - & - & - & - & - & - & - & - & - & - \\
\hline Malic acid & + & \pm & $+1-$ & + & + & \pm & + & - & - & - & - & - \\
\hline Citrate & + & \pm & - & \pm & \pm & - & \pm & - & - & - & - & - \\
\hline Phenylacetic acid & \pm & - & - & - & - & - & - & - & - & - & - & - \\
\hline
\end{tabular}

${ }^{\star}$ Data from Suyama et al. (1999).

description of each novel species. Differential phenotypical characteristics are indicated in Table 1. Several organic substrates were only utilized after prolonged incubation by a small number of cells streaked on agar, probably involving mutational events. Some traits of the original description of Pelomonas saccharophila do not correspond to our observations with strains CCUG $32988^{\mathrm{T}}$ and LMG $2256^{\mathrm{T}}$. In our hands, Pelomonas saccharophila did not grow at $37{ }^{\circ} \mathrm{C}$ and was unable to hydrolyse gelatin or to grow on citrate. Also differences between both strains were detected in the assimilation of D-mannose and malic acid, indicated as $+/-$ in Table 1 .

The 16S rRNA, internally transcribed spacer 1 (ITS, region between the $16 \mathrm{~S}$ and $23 \mathrm{~S}$ genes), nifH and Rubisco genes were amplified from total DNA. The almost-complete $16 \mathrm{~S}$ rRNA genes (1335 bp) were amplified by PCR using the primers 16F27 and 16R1492, and sequenced as described previously (Gomila et al., 2005). The primers 16F945 (5'GGGCCCGCACAAGCGGTGG-3') and 23R458 (5'-CTTTCCCTCACGGTAC- $3^{\prime}$ ) were used for the amplification of
ITS1 (Guasp et al., 2000). A fragment of approximately $388 \mathrm{bp}$ of the nifH gene (encoding the dinitrogenase reductase iron protein) was also amplified using primers 19F (5'-GCIWTYTAYGGIAARGGIGG-3') and 407R (5'AAICCRCCRCAIACIACRTC-3'), where I represents inosine, $\mathrm{R}$ represents $\mathrm{A}$ or $\mathrm{G}, \mathrm{W}$ represents $\mathrm{A}$ or $\mathrm{T}$ and $\mathrm{Y}$ represents $\mathrm{C}$ or $\mathrm{T}$. The reaction conditions were an initial step of $5 \mathrm{~min}$ at $94{ }^{\circ} \mathrm{C}$, followed by $30 \mathrm{~s}$ at $94{ }^{\circ} \mathrm{C}, 1 \mathrm{~min}$ at $50{ }^{\circ} \mathrm{C}$ and $30 \mathrm{~s}$ at $72{ }^{\circ} \mathrm{C}$ for 40 cycles, and a final step of $72{ }^{\circ} \mathrm{C}$ for $10 \mathrm{~min}$ (Ueda et al., 1995). For the amplification of Rubisco genes, three primer sets specific for the form I enzyme (green and red, $c b b L$ ) and the form II enzyme were employed (Giri et al., 2004; Selesi et al., 2005). Red-like $c b b L$ genes were amplified with primer pair $c b b L R 1 \mathrm{~F}\left(5^{\prime}-\right.$ AAGGAYGACGAGAACATC-3') and cbbLR1R (5'-TCGGTCGGSGTGTAGTTGAA-3'). Amplification of greenlike $c b b L$ gene primers $c b b L$ G1F ( $5^{\prime}$-GGCAACGTGTTCGGSTTCAA-3') and $c b b L G 1 R$ ( $5^{\prime}$-TTGATCTCTTT CCACGTTTCC-3') were used, where $S$ represents $G$ or $C$. The cycle conditions for $c b b L$-specific primers were as follows: initial denaturation at $95{ }^{\circ} \mathrm{C}$ for $4 \mathrm{~min}$, followed by 32 
cycles of $1 \mathrm{~min}$ at $95{ }^{\circ} \mathrm{C}$ for denaturation, $1 \mathrm{~min}$ of annealing at $62{ }^{\circ} \mathrm{C}$ with the red-like and at $60{ }^{\circ} \mathrm{C}$ with the green-like $c b b L$ primers, 1 min of elongation at $72{ }^{\circ} \mathrm{C}$, and a final extension step of $10 \mathrm{~min}$ at $72{ }^{\circ} \mathrm{C}$. Form II Rubisco genes were amplified with the primer pair $c b b M F\left(5^{\prime}\right.$ ATCATCAARCCSAARCTSGGCCTGCGTCCC- $3^{\prime}$ ) and cbbMR ( $5^{\prime}$-MGAGGTGACSGCRCCGTGRCCRGCMCGRTG-3'), where $\mathrm{M}$ represents $\mathrm{A}$ or $\mathrm{C}$. The PCR conditions were modified to an initial denaturation at $95{ }^{\circ} \mathrm{C}$ for $5 \mathrm{~min}$, followed by 30 cycles of $1 \mathrm{~min}$ at $94{ }^{\circ} \mathrm{C}, 1 \mathrm{~min}$ at $65{ }^{\circ} \mathrm{C}$ and $1 \mathrm{~min}$ at $72{ }^{\circ} \mathrm{C}$, and a final extension at $72{ }^{\circ} \mathrm{C}$ for 10 min. Primers hoxF1 (5'-GAYCCNRTNACNMGNATHGARGGNCA-3') and hoxR1 (5'-ACRTGNRYBSVRCANSCVRDVMANGGRTC-3') for the amplification of the hydrogenase gene hox $G$ were designed from the alignment of different hoxG sequences retrieved from databases, where $\mathrm{H}$ represents $\mathrm{A}, \mathrm{C}$ or $\mathrm{T}, \mathrm{B}$ is $\mathrm{G}, \mathrm{T}$ or $\mathrm{C}, \mathrm{V}$ is $\mathrm{G}, \mathrm{C}$ or $\mathrm{A}, \mathrm{D}$ is $\mathrm{G}, \mathrm{T}$ or $\mathrm{A}$, and $\mathrm{N}$ represents $\mathrm{G}, \mathrm{A}, \mathrm{T}$ or $\mathrm{C}$. The touchdown PCR programme used was an initial denaturation step of $5 \mathrm{~min}$ at $94{ }^{\circ} \mathrm{C}$ followed by 5 cycles of $94{ }^{\circ} \mathrm{C}$ for $1 \mathrm{~min}, 65{ }^{\circ} \mathrm{C}$ for $1 \mathrm{~min}$ and $72{ }^{\circ} \mathrm{C}$ for $105 \mathrm{~s}$, then 20 cycles of $94{ }^{\circ} \mathrm{C}$ for $1 \mathrm{~min}, 65^{\circ} \mathrm{C}$ for $1 \mathrm{~min}$ (decreasing $0.5{ }^{\circ} \mathrm{C}$ per cycle) and $72{ }^{\circ} \mathrm{C}$ for $105 \mathrm{~s}$; and 15 cycles of $94{ }^{\circ} \mathrm{C}$ for $1 \mathrm{~min}, 55{ }^{\circ} \mathrm{C}$ for $1 \mathrm{~min}$ and $72{ }^{\circ} \mathrm{C}$ $105 \mathrm{~s}$; and finally extension at $72{ }^{\circ} \mathrm{C}$ for $10 \mathrm{~min}$. PCR amplification was performed with the Personal DNA Thermocycler (Eppendorf). Individual reaction mixtures contained $10 \mathrm{mM}$ Tris/HCl, pH 9.0, $50 \mathrm{mM} \mathrm{KCl}, 1.5 \mathrm{mM}$ $\mathrm{MgCl}_{2}, 200 \mu \mathrm{M}$ each of the four deoxynucleoside triphosphates (Amersham Biosciences), $0.5 \mu \mathrm{l}$ of both forward and reverse primer solutions $(10 \mu \mathrm{M}), 1.5 \mathrm{U}$ Taq DNA polymerase (Amersham Biosciences), and 1-3 $\mu$ l template DNA in a total volume of $50 \mu \mathrm{l}$. For the Rubisco, nifH and hoxG genes, the amount of primers was higher: $0.5 \mu \mathrm{l}$ of both forward and reverse primer solutions $(100 \mu \mathrm{M})$. A $5 \mu \mathrm{l}$ sample of the amplified products was analysed by electrophoresis in a $1 \%(\mathrm{w} / \mathrm{v})$ agarose gel for $16 \mathrm{~S} \mathrm{rRNA}$ products and in a $2 \%(\mathrm{w} / \mathrm{v})$ agarose gel for the other products, and stained with ethidium bromide. For sequencing reactions, the same primers and conditions were used. The amplified products were purified with Microcon centrifugal filter devices (Amicon; Millipore) according to the manufacturer's instructions. Sequencing reactions were carried out using the ABI Prism Big Dye version 3.1 Terminator Cycle sequencing kit and the sequences were read with an automatic sequence analyser (ABI Prism 3730 DNA Sequencer; Applied Biosystems). The 16S rRNA, ITS1, nifH and Rubisco gene sequences were aligned with the closest relatives retrieved from the BLAST nucleotide sequence database. The alignment was done using a hierarchical method for multiple alignments implemented in the CLUSTAL_X program (Thompson et al., 1997). Automatically aligned sequences were checked manually. Similarities and evolutionary distances were calculated with programs contained in PHYLIP (Phylogenetic Inference Package, version 3.5c) (Felsenstein, 1989). Gene distances were calculated from nucleotide sequences by the Jukes-Cantor method (Jukes
\& Cantor, 1969) and dendrograms were generated by the neighbour-joining, minimum-evolution and maximumparsimony methods. Bootstrap analysis of 1000 replications was also performed. Topologies of the trees were visualized with the TreeView program (Page, 1996). The dendrograms showed the same topology and only the neighbour-joining tree is given in Fig. 2 .

The novel isolates and Pseudomonas sp. DSM 2583 clustered in the same phylogenetic branch of the tree based on the $16 \mathrm{~S}$ rRNA gene sequences together with the Pelomonas saccharophila type strain, showing a level of sequence similarity higher than $99.0 \%$. M. chitosanitabida strains (97.2-98.5\%) and $R$. depolymerans (96.3-97.9\%) were the closest neighbours (Supplementary Table S1 available in IJSEM Online). The results of all treeing methods were consistent with the affiliation of the haemodialysis isolates and DSM 2583 with the genus Pelomonas; however, they grouped separately from the Pelomonas saccharophila type strain with 99.0-99.2\% similarity and from the industrial water isolates with $98.9-99.2 \%$ similarity. The latter strains were also grouped in the Pelomonas branch with $99.8 \%$ similarity to the Pelomonas saccharophila type strain. Intragroup distances were $99.8-100.0 \%$ similarity for the haemodialysis water strains and $99.9-100.0 \%$ similarity for the industrial water strains. These groupings were maintained when the ITS1 gene sequence was analysed (Supplementary Fig. S1 available in IJSEM Online), showing high similarity (91.0$92.0 \%$ ) within the groups affiliated with the genus Pelomonas and lower similarity $(70.0-73.0 \%)$ to the most closely related genera. Two ITS1 amplicons were detected in the $R$. depolymerans type strain and not sequenced. The genes for the green form I $(c b b L)$ and for form II ( $c b b M)$ Rubisco did not amplify in any of the strains. However, $c b b L$ red form I Rubisco, nifH (nitrogenase) and hoxG (hydrogenase) genes were amplified from the haemodialysis water isolates as well as from strains DSM 2583 and Pelomonas saccharophila type strain, but not from the industrial water isolates. The Rubisco and nitrogenase genes were sequenced and the phylogenetic trees derived from the sequences showed the same groupings as the 16S rRNA and ITS1 gene sequences (Supplementary Fig. S2 available in IJSEM Online).

Gas chromatography of fatty acid methyl esters (FAME) was performed at CCUG in a highly standardized way close to that of the MIDI Sherlock MIS system. Fatty acids were identified and quantified and the relative amount of each fatty acid in a strain was expressed as a percentage of the total fatty acids in the profile of that strain. The major cellular fatty acids detected were cis-9-hexadecanoic and hexadecanoic acids (Table 2). Clear differences to $M$. chitosanitabida IAM $14711^{\mathrm{T}}$ and $R$. depolymerans CCUG $52219^{\mathrm{T}}$ were apparent in the relative amounts of dodecanoic and cis-11-octadecanoic acids. The strains grouped in the three phylogenetic branches according to the $16 \mathrm{~S}$ rRNA, ITS1, Rubisco and nifH genes could be distinguished chemotaxonomically based on the amounts of 2hydroxy-dodecanoic and octadecanoic acid. 


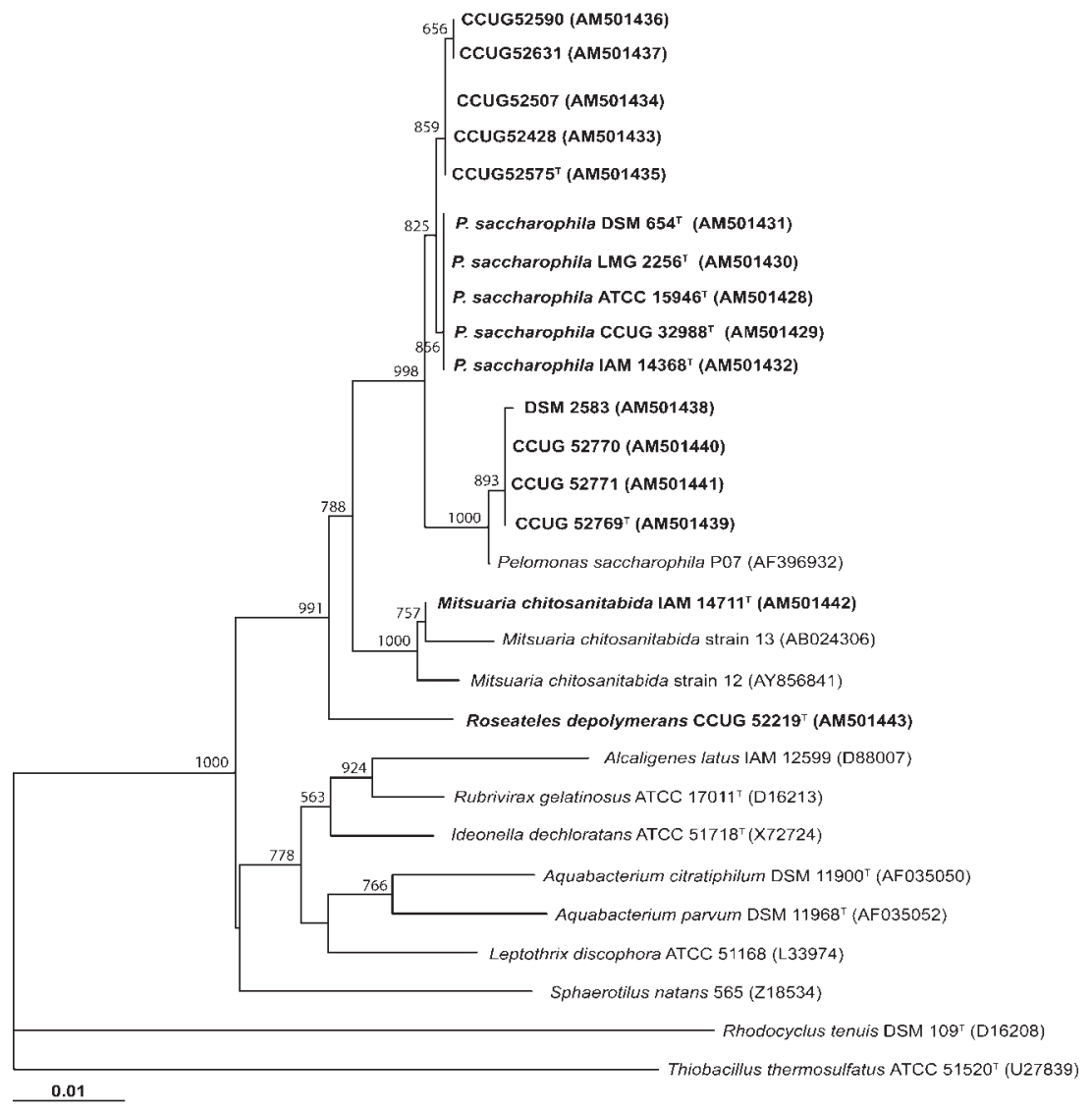

Fig. 2. A neighbour-joining phylogenetic tree based on the 16S rRNA gene sequence (1335 bp) showing the relationships of the novel isolates with Pelomonas saccharophila and related genera of the class Betaproteobacteria. Bootstrap values greater than 500 based on 1000 replications are indicated at branching nodes. Sequences indicated in bold were determined in this study.

DNA was isolated following the method of Marmur (1961). DNA-DNA hybridizations were performed in duplicate using a non-radioactive method as described by Ziemke et al. (1998). Reference DNAs of one strain of each group $\left(\right.$ DSM $654^{\mathrm{T}}$, CCUG $52769^{\mathrm{T}}$, CCUG 52219 , IAM $14711^{\mathrm{T}}$ and CCUG 52575 ${ }^{\mathrm{T}}$ ) were double-labelled with DIG-11dUTP and biotin-16-dUTP using a Nick Translation kit (Roche). DNA-DNA hybridizations were performed using chromosomal DNA of each type strain as a probe against the other strains (Supplementary Table S2 available in IJSEM Online). Similarity values between strains of the same phylogenetic branch were higher than $85.0 \%$ and lower than $70.0 \%$ between members of two separate branches, when the mean values were considered. This indicates that three different genomic groups, coinciding with the phylogenetic groups, can be delineated within the genus Pelomonas.

Table 2. Fatty acid composition (\%)

Strains: 1, Pelomonas saccharophila CCUG $32988^{\mathrm{T}}$; 2, DSM 2583; 3, CCUG 52769 ${ }^{\mathrm{T}}$; 4, CCUG 52770; 5, CCUG 52771; 6, CCUG 52428; 7 , CCUG 52507; 8, CCUG 52575 ${ }^{\mathrm{T}}$; 9, CCUG 52590; 10, CCUG 52631; 11, M. chitosanitabida IAM $14711^{\mathrm{T}} ; 12$, R. depolymerans CCUG 52219 ${ }^{\mathrm{T}}$.

\begin{tabular}{|c|c|c|c|c|c|c|c|c|c|c|c|c|}
\hline Fatty acid & 1 & 2 & 3 & 4 & 5 & 6 & 7 & 8 & 9 & 10 & 11 & 12 \\
\hline $12: 0$ & 7.4 & 4.1 & 4.9 & 5.8 & 5.8 & 6.8 & 6.3 & 7.4 & 4.9 & 6.5 & - & 0.9 \\
\hline $14: 0$ & 1.3 & 0.8 & 1.0 & 1.0 & 1.0 & 1.7 & 1.6 & 1.8 & 1.5 & 1.4 & 0.8 & 1.2 \\
\hline $15: 0$ & 1.0 & - & 0.6 & 0.6 & 0.6 & 1.3 & 1.3 & 1.4 & 1.2 & 1.6 & 0.2 & 1.3 \\
\hline $16: 1 \omega 7 c$ & 41.9 & 47.6 & 47.7 & 45.1 & 45.5 & 44.2 & 44.3 & 43.1 & 46.7 & 43.6 & 44.1 & 42.8 \\
\hline $18: 1 \omega 9 c$ & - & - & - & - & - & - & - & - & - & - & - & 0.3 \\
\hline $18: 1 \omega 7 c / 12 t / 9 t$ & 3.3 & 3.2 & 3.7 & 4.1 & 3.6 & 3.3 & 4.9 & 3.2 & 4.1 & 4.0 & 12.9 & 13.0 \\
\hline $18: 0$ & - & 0.4 & 0.5 & 0.5 & 0.5 & - & - & - & - & - & 0.5 & 0.4 \\
\hline Unidentified & - & - & - & 0.4 & 0.4 & - & - & - & - & - & - & 0.1 \\
\hline
\end{tabular}


Based on the genetic and phenotypic analyses, we conclude that strains CCUG 52769 ${ }^{\mathrm{T}}$, CCUG 52770 and CCUG 52771, together with DSM 2583, constitute a novel species and that strains CCUG 52428, CCUG 52507, CCUG 52575 ${ }^{\mathrm{T}}$, CCUG 52590 and CCUG 52631 represent another species of the genus Pelomonas. For the first group, the name Pelomonas puraquae, sp. nov. is proposed. The type strain of Pelomonas puraquae is CCUG $52769^{\mathrm{T}}$. For the second group, the name Pelomonas aquatica sp. nov. is proposed. The type strain of Pelomonas aquatica is CCUG $52575^{\mathrm{T}}$.

\section{Description of Pelomonas aquatica sp. nov.}

Pelomonas aquatica (a.qua'ti.ca. L. fem. adj. aquatica living in water).

The characteristics are the same as those given in the description of the genus, with the following additional traits. Colonies are small $(1-2 \mathrm{~mm})$, yellowish, dark and opaque and difficult to recultivate after 1 week of incubation. Cells are rod-shaped $(2 \mu \mathrm{m}$ in length and $0.5 \mu \mathrm{m}$ in width). Unable to grow autotrophically with hydrogen. Growth occurs at $20-37^{\circ} \mathrm{C}$, with an optimal temperature at about $30^{\circ} \mathrm{C}$; unable to grow at 10 and $45{ }^{\circ} \mathrm{C}$. Positive for nitrate reduction and $\beta$-glucosidase, and negative for urease, gelatin hydrolysis, $\beta$-galactosidase and glucose fermentation. Unable to grow without combined nitrogen. Unable to grow in D-glucose, Larabinose, D-mannose, D-mannitol, $N$-acetyl-D-glucosamine, maltose, gluconate, capric acid, adipic acid, malic acid, citrate and phenylacetate. Able to utilize: $\alpha$-cyclodextrin, D-fructose, dextrin, uridine, glycogen, thymidine, Tween 40, DL-lactic acid, L-proline, trehalose, L-asparagine, glycerol, L-glutamic acid, DL- $\alpha$-glycerol phosphate, pyruvic acid methyl ester and $\beta$-hydroxybutyric acid.

The type strain, CCUG $52575^{\mathrm{T}}\left(=\mathrm{CECT} 7233^{\mathrm{T}}\right)$, was isolated from industrial water in Sweden.

\section{Description of Pelomonas puraquae sp. nov.}

Pelomonas puraquae (pur.a.quae. L. adj. purus - a -um pure; L. n. aqua water; N.L. gen. n. puraquae of pure water).

The characteristics are the same as those given in the description of the genus, with the following additional traits. Colonies are $4-5 \mathrm{~mm}$ in diameter, pale brown being darker in the centre, circular, raised with entire margin, smooth and translucent. Can easily be removed from the agar. Cells are rod-shaped $(2 \mu \mathrm{m}$ in length and $0.5 \mu \mathrm{m}$ in width). Able to grow autotrophically with hydrogen. Growth occurs at $10-37{ }^{\circ} \mathrm{C}$, with an optimal temperature about $37{ }^{\circ} \mathrm{C}$; unable to grow at 4 and $45^{\circ} \mathrm{C}$. Variable for nitrate reduction and positive for $\beta$-glucosidase, $\beta$ galactosidase and gelatin hydrolysis, negative for urease and glucose fermentation. Able to grow in L-arabinose, D-glucose, maltose, sucrose, D-cellobiose, acetate, $\alpha$-ketoglutarate, fumarate, glutamate, lactate, malic acid, pyruvate, L-arginine, L-asparagine, L-histidine, L-serine and L-valine. Variable growth for citrate and succinate.
Negative for D-mannose, D-mannitol, $N$-acetyl-Dglucosamine, gluconate, capric acid, adipic acid and phenylacetate. Able to utilize Tweens 40 and 80 , pyruvic acid methyl ester, $\beta$-hydroxybutyric acid and glycyl Lglutamic acid.

The type strain, CCUG $52769^{\mathrm{T}}\left(=\mathrm{CECT} 7234^{\mathrm{T}}\right)$, was isolated from haemodialysis water in Mallorca, Spain.

\section{Acknowledgements}

This work was supported in part by the CICYT (Spain) grant REN2002-04035-CO3-01 and by the 'I Plà Balear de Recerca I Desenvolupament Tecnològic de les Illes Balears'. M.G. was the recipient of a predoctoral fellowship from the Spanish Ministerio de Educación y Ciencia. We greatly acknowledge the excellent technical assistance of Gertrud Stahlhut, the help of Bernhard Kusian in designing primers for the hydrogenase genes, and constructive discussions with Norberto J. Palleroni and J. Gascó.

\section{References}

Aragno, M. \& Schlegel, H. S. (1992). The mesophilic hydrogenoxidizing (Knallgas) bacteria. In The Prokaryotes, vol. I, pp. 344-384, 2nd edn. Edited by A. Balows, H. G. Trüper, M. Dworkin, W. Harder \& K. H. Schleifer. Springer-Verlag.

Barraquio, W. L., Padre, B. C., Jr, Watanabe, I. \& Knowles, R. (1986). Nitrogen fixation by Pseudomonas saccharophila Doudoroff ATCC 15946. J Gen Microbiol 132, 237-241.

Cowan, S. T. (1974). Cowan and Steel's Manual for the Identification of Medical Bacteria, 2nd edn. Cambridge University Press.

Doudoroff, M. (1940). The oxidative assimilation of sugars and related substances by Pseudomonas saccharophila with a contribution to the problem of the direct respiration of $\mathrm{di}$ - and polysaccharides. Enzymologia 9, 59-72.

Doudoroff, M., Palleroni, N. J., McGee, J. \& Ohara, M. (1956). Metabolism of carbohydrates by Pseudomonas saccharophila. J Bacteriol 71, 196-201.

Felsenstein, J. (1989). PHYLIP - phylogeny inference package (version 3.2). Cladistics 5, 164-166.

Giri, B. J., Bano, N. \& Hollibaugh, J. T. (2004). Distribution of RuBisCO genotypes along a redox gradient in Mono Lake, California. Appl Environ Microbiol 70, 3443-3448.

Gomila, M., Gascó, J., Busquets, A., Gil, J., Bernabeu, R., Buades, J. M. \& Lalucat, J. (2005). Identification of culturable bacteria present in haemodialysis water and fluid. FEMS Microbiol Ecol 52, 101-114.

Gomila, M., Gascó, J., Gil, J., Bernabeu, R., Iñigo, V. \& Lalucat, J. (2006). A molecular microbial ecology approach to studying hemodialysis water and fluid. Kidney Int 70, 1567-1576.

Guasp, C., Moore, E. R. B., Lalucat, J. \& Bennasar, A. (2000). Utility of internally-transcribed 16S-23S rDNA spacer regions for the definition of Pseudomonas stutzeri genomovars and other Pseudomonas species. Int J Syst Evol Microbiol 50, 1629-1639.

Jukes, T. H. \& Cantor, C. R. (1969). Evolution of protein molecules. In Mammalian Protein Metabolism, vol. 3, pp. 21-132. Edited by H. N. Munro. New York: Academic Press.

Kulakov, L. A., McAlister, M. B., Ogden, K. L., Larkin, M. J. \& O'Hanlon, J. F. (2002). Analysis of bacteria contaminating ultrapure water in industrial systems. Appl Environ Microbiol 68, $1548-1555$. 
Lalucat, J. (1988). Analysis of refractile (R) bodies. In Methods in Microbiology - Electron Microscopy in Microbiology, vol. 20, pp. 79-90. Edited by F. Mayer. Academic Press.

Marmur, J. (1961). A procedure for the isolation of deoxyribonucleic acid from microorganisms. J Mol Biol 3, 208-218.

Page, R. D. M. (1996). TreeView: an application to display phylogenetic trees on personal computers. Comput Appl Biosci 12, 357-358.

Palleroni, N. J. (1980). Isolation and properties of a new hydrogen bacterium related to Pseudomonas saccharophila. J Gen Microbiol 117, 155-161.

Reasoner, D. J. \& Geldreich, E. E. (1985). A new medium for the enumeration and subculture of bacteria from potable water. Appl Environ Microbiol 49, 1-7.

Selesi, D., Schmid, M. \& Hartmann, A. (2005). Diversity of green-like and red-like ribulose-1,5-bisphosphate carboxylase/oxygenase largesubunit genes $(c b b L)$ in differently managed agricultural soils. Appl Environ Microbiol 71, 175-184.

Stringfellow, W. T. \& Aitken, M. D. (1995). Competitive metabolism of naphthalene, methylnaphthalenes, and fluorene by phenanthrenedegrading pseudomonads. Appl Environ Microbiol 61, 357-362.
Suyama, T., Shigematsu, T., Takaichi, S., Nodasaka, Y., Fujikawa, S., Hosoya, H., Tokiwa, Y., Kanagawa, T. \& Hanada, S. (1999). Roseateles depolymerans gen. nov., sp. nov., a new bacteriochlorophyll $a$ containing obligate aerobe belonging to the $\beta$-subclass of the proteobacteria. Int J Syst Bacteriol 49, 449-457.

Thompson, J. D., Gibson, T. J., Plewniak, F., Jeanmougin, F. \& Higgins, D. G. (1997). The CLUSTAL_X windows interface: flexible strategies for multiple sequence alignment aided by quality analysis tools. Nucleic Acids Res 25, 4876-4882.

Ueda, T., Suga, Y., Yahiro, N. \& Matsuguchi, T. (1995). Remarkable $\mathrm{N}_{2}$-fixing bacterial diversity detected in rice roots by molecular evolutionary analysis of nifH gene sequences. J Bacteriol 177, 1414-1417.

Xie, C. H. \& Yokota, A. (2005). Reclassification of Alcaligenes latus strains IAM $12599^{\mathrm{T}}$ and IAM 12664 and Pseudomonas saccharophila as Azohydromonas lata gen. nov., comb. nov., Azohydromonas australiaca sp. nov. and Pelomonas saccharophila gen. nov., comb. nov. respectively. Int J Syst Evol Microbiol 55, 2419-2425.

Ziemke, F., Höfle, M. G., Lalucat, J. \& Rosselló-Mora, R. (1998). Reclassification of Shewanella putrefaciens Owen's genomic group II as Shewanella baltica sp. nov. Int J Syst Bacteriol 48, 179-186. 